\title{
Flipped Classroom as a Supporting Plan for Iranian EFL Learners' English Improvement in Super Intensive Courses
}

\author{
Mustapha Hajebi \\ Department of Education, Bandar Abbas, Iran
}

\begin{abstract}
The present study sought to investigate the effectiveness of flipped classroom as a supporting plan for Iranian EFL learners' English improvement in super intensive courses. The participants included a sample of 40 students from Accent English language institute of Bandar Abbas, Iran, then divided into two experimental and control groups randomly. The dependent variable was English improvement and independent variable was watching and learning by films that gathered by Hajebi (2020). This study took in 30 sessions and involved treatment, pre-test, post-test and random assignment that it was in line with true experimental design, so the design of the current study was quantitative design. To analyze the data the frequencies and percentage of each item in the questionnaires computed with the aid of SPSS. The findings indicated that not only did flipped model of instruction improve students' English performance but also it improved their overall attitudes and beliefs towards it and boosted students' motivation and learning. Furthermore, this study may offer some implications for language teaching and learning.
\end{abstract}

Index Terms - English improvement, supper intensive course, flipped classroom

\section{INTRODUCTION}

Flipped teaching and learning in education has not only changed the traditional learning patterns and teacher-center learning, but also improving student learning achievement and increase interaction among learners and teachers (Hwang \&Lai, 2017). Apart from the typical classroom schedules for learning regular programs which include short and widely spaced sessions over a long period of time also intensive programs are available for L2 learners that include an extensive amount of hours of contact with the L2 over a short period of time (Collins, Halter, Lightbrown \& Spada, 1999; Lightbown \& Spada 1991). Even though the total amount of time on task in these programs may still be far from the amount of L1 exposure students receive. There is some variability in the design of intensive courses, but in general these programs tend to provide L2 input and output practice for at least four hours every day, five days a week (Serrano, 2011). Durrant and Schmitt, (2010) says It seems reasonable to expect that such a schedule will be more beneficial for the acquisition language skills. In other words, the spacing of the presented may be hypothesized to be more conducive to learning in an intensive program than in a regular program, where the spacing intervals are probably too wide to allow recall of former presentations of the items (as cited in Serrano, Stengers, \& Housen, 2015).

As Pirasteh and Mirzaeian, (2015) believed difficulties and obstacles in the learning of English in institutes in Iran encourage teachers and researchers to look for ways to overcome these barriers. Teachers should make learning interesting for students and make them responsible for their own learning. One way is to encourage students and teachers to use available technologies rather than using traditional methods of language learning and teaching. Today Iranian students have at least one mobile phone that is always and everywhere with them. It can be used as an educational tool that is always available and does not have some of the limitations of traditional methods.

This study aims at highlighting the educational shift of the emergence of flipped classroom as a supporting plan for Iranian EFL learners' English improvement in super intensive courses. The main focus is on how EFL students of Accent English Language Institute in Bandar Abbas update themselves to use mobile technologies to support their English language level, mainly the way they improve their skills in a flipped classroom.

\section{Flipped Classroom Resources}

Schools have access to numerous platforms and online sources for flipping the classroom. One of the simplest resources that a teacher can use is YouTube to find videos that other educators have produced within specific subjects. A simple internet search showed an accumulation of materials including the Khan Academy for video presentations (Tucker, 2012). The Khan Academy is an online video library for educational use and is designed for educators. As more teachers become comfortable with the use of digital technology, the increase in educational videos will continue.

Teachers can also produce their own videos to provide a more familiar voice to the students they teach, for example; English with Mr Hajebi is an application that contains 49 videos for basic level and 23 lives with different teachers around the world about English pedagogy. The uses of online communities such as Blackboard, Camtasia, Coursera, Schoology, Haiku, and Moodle have also found their way into the flipped classroom with great success (Addy \& Stevenson, 2012; Brame, 2012; Bull et al., 2012; Caverly \& McDaniel, 2010; Dickerson et al., 2011; Fulton, 2012). 
These choices can help teachers of all technology levels. The choice of technology helped good teachers become better even if the technology was of poor quality.

\section{Self-Efficacy}

Teachers have known for years that when students use their own experiences in the classroom, they take ownership of their own learning and their desire to learn more about a subject because it becomes personal (Ajzen, 2005). Positive personal experiences in learning can elicit an increase in classroom performance (Ajzen, 2005). People with higher selfefficacy set higher personal goals and have been shown to have a better commitment to accomplishing those goals (Bandura, 1989). The idea is that when a student believes they can accomplish a task, they are more academically motivated to complete the task (Clayton, Blumber, \& Auld, 2010).

\section{Self-Efficacy and Learning}

Students who believe in their abilities in the classroom are able to rely on their own learning abilities when educational challenges are presented to them (Bandura, 1997). There have been numerous papers and research done on student self-efficacy and its place in the classroom (Arslan, 2013; Bandura, 1997; Louis \& Mistele, 2012; Peters, 2013; Velayutham, Aldridge, \& Fraser, 2012). Arslan (2013) identifies a reciprocal effect between self-efficacy and academic achievement with self-efficacy predicting achievement and achievement as a source of self-efficacy. Students that possess higher self-efficacy have also shown to perform better in math and science classes and pursue stream fields (Peters, 2013).

\section{Self-Efficacy and the Flipped Classroom}

Teachers that implemented the flipped classroom model showed that students performed better on exams, they were better motivated, teachers were impressed by the content of work produced by students, and teachers identified a reduction in student stress levels (Marlowe, 2012). Students that displayed a positive effect from class also displayed an increase in self-efficacy (Ajzen, 2012). Many students in a flipped classroom showed an improvement in behavior and retention of material (Nolan \& Washington, 2013). The flipped classroom's use of technology and web-based learning is also showing promise with students that already show strong self-efficacy.

\section{Mobile Learning}

In recent years, the world has witnessed an explosion in the growth of mobile learning across various sectors of education. In fact, whenever referring to mobile learning, many authors use the term mobile as synonym to mobile phone, amounting to a misconception to the whole concept (Eteokleous \& Laouris, 2005). However, this new concept is still ill-defined because of the difficulty in characterizing the unique nature of mobile learning. It is to say that many researchers agree upon the difficulty of providing an exact definition of what constitutes mobile learning, claimed Kukulska-Hulme \& Traxler (cited in Hockly, 2013). Accordingly, Winters stated that mobile learning has been defined from different perspectives varying from particular experiences, uses, and backgrounds; seeming to be all thing to all people (cited in Sharples, 2006). In other words, the concept of mobile learning is defined from different angles, depending on various variables.

Traxler (2009) claimed that M- learning continued to gain identity and definition rather than lose them. Thus, multidimensional definitions have been provided to the concept of mobile learning. In the past, mobile learning has often been defined in terms of its use of mobile technologies. More recent definitions espouse it to e-learning and informal learning, as well as the mobility of the learner. A formal definition provided by UNESCO (2014) states that mobile learning involves the use of mobile technology, either alone or in combination with other information and communication technology (ICT), to enable learning anytime and anywhere. Another simple definition was provided by Quinn (2000), stating that mobile learning is learning which takes place with the assistance of mobile devices (cited in Eteokleous \& Laouris, 2005). In line with this definition, many authors also shed light on the technological aspect while identifying M- learning because they consider this new technology as a "pervasive medium that may assist us in combining work, study, and leisure time in meaningful ways" (cited in Eteokleous \& Laouris, 2005).

Traxler (2005) explicates that mobile learning is the provision of education and training on mobile devices. Another technocentric definition was provided by O'Malley et al. (2003) saying that it is any sort of learning that takes place when the learner is not at a fixed, predetermined location, or learning happening when the learner exploits learning opportunities offered by mobile technologies. Accordingly, The Molenet initiative, a program across the UK vocational sector, believes that mlearning is exploiting the ubiquity of handheld hardware, wireless networking and mobile telephony to enhance and extend the reach of teaching and learning processes (cited in Traxler, 2009). Therefore, Desmond (2005) took a similar position, asserting that when defining mobile learning, the focus should be on mobility. He pointed out, "mobile learning should be restricted to learning on devices which a lady can carry in her handbag or a gentleman can carry in his pocket" (cited in Traxler, 2009, p. 2). Therefore, the portability of the mobile device should be taken into consideration to facilitate the learning process.

Mobile learning is sometimes viewed as a mere extension of e-learning. Formal definitions from European and Government agencies espouse the term mobile learning to the concept of e-learning, stated Winters (2006) (cited in Sharples, 2006). Most researchers and educators consider mobile learning as an immediate descendent of e-learning. To elucidate, Pikwart et al. (2003) believed that e-learning is learning assisted by electronic tools and media, following this, mlearning is e-learning that uses mobile technology and wireless transmission (cited in Eteokleous \& Laouris, 2005). It is to say that mobile learning has always led to e-learning, as Traxler (2007) pointed out that mobile learning therefore 
should be understood as both "a continuation of 'conventional' e-learning and a reaction to this 'conventional' elearning and to its perceived inadequacies and limitations" (p. 1). Chinnery (2006) took a similar position by asserting that mobile learning is a burgeoning subdivision of the e-learning movement. Quinn (2000), who viewed mlearning as e-learning through mobile computational devices (cited in Traxler, 2009, p. 2), also claimed that mlearning is the intersection of mobile computing and e-learning (cited in Tomei, 2008).

\section{Mobile Learning as an Informal Way of Learning}

Another perspective on mobile learning sheds light on its informal aspect, leading to juxtaposition between mobile learning and formal education as well as linking other interrelated aspects of M-learning such as context and learner's perspective. Global Encyclopedia of Information provided a simple definition of informal learning; in which both goals and processes of learning are set by the learner, and where the learning is situated rather than pre-established (Tomei, 2018). Along the same vein, a definition of mobile learning provided by Wikipedia (2014), saying that M-learning is learning across multiple contexts, through social and content interactions, using personal electronic devices. Moreover, mobile learning is considered as an opportunity to be creative. Accordingly, Sharples (2007) pointed out that "mobile learning gives us the opportunity to design learning differently, to create extended learning communities, to provide expertise on demand, and to support a lifetime of learning" (cited in Ticheler, 2010, "Mobile Learning"). Walker (2007) shared focusing on context; he stated that M-learning is not merely the use of portable devices, but learning across contexts (cited in Ticheler, 2010). It is to say that M-learning supports EFL learner's individual learning style, providing the opportunity to be self-creative and to learn in different contexts.

\section{Mobile Technology}

Nowadays, mobile devices make mobile learning possible by delivery of various learning materials and content to learners. Indeed, a wide range of activities related to language learning are supported by mobile and palmtop devices. Trifanova et al. (2004) defined mobile devices as “....any device that is small, autonomous and unobtrusive enough to accompany us in every moment" (cited in Kukulska-Hulme \& Shield, 2007, p. 3). An investigation of the MALL literature reveals that the research in the field has tend to employ devices such as mobile phones/smartphones and palmtop computers (Kukulska-Hulme \& Shield, 2007). Such portable devices-referred to in popular and scholarly literature as "mobile, wireless, handheld or nomadic- are now social staples" (Chinnery, 2006, p. 9). Mobile technologies can be classified in terms of personalization, share ability and portability. Naismith, Lonsdale, Vavoulva and Sharples (2004) provided a classification of mobile technologies using the two orthogonal dimensions of personal vs. shared and portable vs. static Learners tend to see mobile devices as a powerful medium in the classroom, enabling them to gather information, study, work, and communicate with both their teachers and classmates effectively. Beatty (2013) illustrated by imagining the situation: a teacher writes a detailed assignment on the board with much efforts, she asks her students to copy it down. When she finishes writing, the students take their mobile phones and snap a photo of the written text. Moreover, EFL learners tend to favor a specific device than another due to the personalization of every device; in terms of use, capacity, and features. While mobile phones, namely iPhones, have typically been the device of choice of many learners in recent years, other mobile devices such as tablet computers are also gaining popularity (Hubbard \& Stockwell, 2013). It is with the iPhone, Android devices, and Windows Phone 7 products, a shift has happened form phones with added-on computing capabilities into mini-computers with phones capabilities (GodwinJones, 2011).

\section{METHODOLOGY}

Since the study involved treatment, pre-test, post-test, and random assignment that it was in line with true experimental design, so the design of the current study was quantitative design.

\section{Participants}

A number of 40 intermediate EFL learners selected from 70 participants as the population. The population selected from Accent English Language Institute of Bandar Abbas, Iran. The participants' ages were between 11 to 40 years old. However, the 40 participants randomly divided into two experimental and control groups.

\section{Instruments}

The first instrument was the PET Test, a test which adopted to normalize the participants. This type of test functioned as a standard measure to verify participants' degree of proficiency in four skills of language including speaking, reading, writing and listening. Moreover, the test indicated that a specific learner had learned the fundamentals of English language and currently had the ability to use language through the skills. Cambridge TESOL Department devised and advised this test to assess the learners' ability in language at intermediate level. The second instrument was a supporting package plan gathered by Hajebi (2020) that contained two types of the films (educational and life style series) and each part had more than 500 hours.

\section{Procedure and Data Collection}

As it is clear, the flipped classroom is an instructional strategy and a type of blended learning that reverses the traditional learning environment by delivering instructional content, often online and outside of the classroom. So, the procedure of collection of the data stepwise as follow:

In order to conduct the study, the researcher administered the PET test to the population in order to form the participants and homogenize them according to their language skills proficiency. After administration of PET test, 40 
students whose scores were one standard deviation bellow and above the mean selected as participation in this study. Then a number of 40 learners randomly divided into two groups as experimental and control group. Each group consisted of 20 intermediate learners.

After selecting and assigning of participants into groups, the groups pre-tested through the KET. The scores on the pre-test collected then calculated and stored for further analysis. Then, the control group treated through the traditional method of teaching English and the experimental group received treatment using methods of flipped classroom. At the first session, the researcher invited the experimental group and taught the basics, methods and rules of flipped classroom. At the second session until the thirtieth which held twice a week, the researcher taught just units of English books for both control and experimental groups. On the other hands, the experimental students had a supporting package plan gathered by Hajebi (2020) to work on it. The supporting plan consisted of two types of the films (educational and life style series). Finally they got ready for the post-test.

\section{RESULTS AND ANALYSIS}

Several statistical analyses were conducted to answer and test the research question and hypothesis designed for this study.

TABLE 1

\begin{tabular}{llll}
\multicolumn{2}{c}{ RESULTS OF DESCRIPTIVE STATISTICS FOR PET AS HOMOGENIZING TEST } \\
\hline Test & Mean & SD & N \\
PET & 59.05 & 9.817 & 70 \\
\hline
\end{tabular}

As the result in table 1 shows, the mean is 59.5 and standard deviation is 9.817 .

TABLE 2

DESCRIPTIVE STATISTICS; PRETEST OF IMPROVEMENT BY GROUPS

\begin{tabular}{llll}
\hline Group & Mean & Std.Error & confidence interval \\
\hline Experimental & 19.400 & .235 & 19.320 \\
Control & 19.080 & .235 & 19.309 \\
\hline
\end{tabular}

TABLE 3

DESCRIPTIVE STATISTICS OF THE OBTAINED SCORES OF BOTH GROUPS IN THE POSTTEST

\begin{tabular}{llll}
\hline Group & $N$ & Mean & Std. Deviation \\
\hline Experimental & 20 & 16.20 & 3.58 \\
Control & 20 & 12.72 & 1.98 \\
\hline
\end{tabular}

As is obvious in Table 3, the mean and standard deviation of the experimental group were 16.20, and 3.58, respectively. However, the mean and standard deviation of the control group were 12.72, and 1.98.

\section{CONCLUSION}

The findings of the study indicated flipped model of instruction had a significant positive effect on EFL students' English development. The results also indicated that the experimental groups had a significantly higher mean on the posttest than control groups. This significant finding might be due to different reasons. One of the possible explanations for the observed results was that flipped classrooms enabled students to benefit more from classroom time and had more time for interaction, learning, assessment, and exploration (Fulton,2012 \& to Boucher, Robertson, Wainner, \& Sanders 2013). The findings of the present study in this respect were in accordance with those of Hung (2015) who found that flipped instructional model in English classes developed students' academic performance in general.

The yielded results confirmed that several students expressed that they learned much better and it appeared that students benefitted from the flipped model of instruction. Most students found instructional videos helpful, engaging, and appropriately challenging.

\section{REFERENCES}

[1] Abaeian, H., \& Samadi, L. (2016). The effect of flipped classroom on Iranian EFL learners' L2 reading comprehension: Focusing on different proficiency levels. Journal of Applied Linguistics and Language Research, 3(6), 295-304.

[2] Al-Harbi, S., \& Alshumaimeri, Y. (2016). The flipped classroom impact in grammar class on EFL Saudi secondary school students' performances and attitudes. English Language Teaching, 9(10), 60-80.

[3] Baker, J. W. (2000). The "classroom flip": Using web course management tools to become the guide by the side. $11^{\text {th }}$ International Conference on College Teaching and Learning, Jacksonville, Florida, United States.

[4] Basal, A. (2015) . The implementation of a flipped classroom in foreign language teaching. Turkish Online Journal of Distance Education, 16(4), 28-37.

[5] Bergmann, J., \& Sams, A. (2012). Flip your Classroom: Reach Every Student, in Every Class, Every Day. Oregon: Courtney Burkholder. 
[6] Boucher, B., Robertson, E., Wainner, R. \& Sanders, B. (2013). "Flipping” Texas State University's physical therapist musculoskeletal curriculum: Implementation of a hybrid learning model. Journal of Physical Therapy Education, 27(3), 72-77.

[7] Cherry, L. (2010). Blended learning: An examination of online learning's impact on face-to-face instruction in high school classrooms (Doctoral dissertation).

[8] Cole, J. E., \& Kritzer, J. B. (2009). Strategies for success: Teaching an online course. Rural Special Education Quarterly, 28(4), 36-40.

[9] Dennis, D. V. (2008). Are assessment data really driving middle school reading instruction? what we can learn from one student's experience. Journal of Adolescent and Adult Literacy, 51, 578-587.http://dx.doi.org/10.1598/JAAL.51.7.5

[10] Elfatah, M.A.,\& Ahmed, A.S. (2016). The effect of a flipping classroom on writing skill in English as a foreign language and students' attitude towards flipping. US-China Foreign Language, 14(2), 98-114.

[11] El Sakka,S.M.F.(2016).A flipped learning based model to develop EFL freshman university students' listening comprehension, Presented at the 4th Scientific international Conference of Curriculum and Instruction Association, Ain Shams University, Egypt,2016.

[12] Enfield, J. (2013).Looking at the impact of the flipped classroom model of instruction on undergraduate multimedia students at CSUN. TechTrends, 57(6), 14-27.

[13] Fulton, K. (2012). Upside down and inside out: Flip your classroom to improve student learning. Learning and Leading with Technology, 38(9), 12-17.

[14] Hsieh, J. S., Wu, W. C. V., \& Marek, M. W. (2016). Using the flipped classroom to enhance EFL learning. Computer Assisted Language Learning, 1-25. http://dx.doi.org/10.1080/09588221.2015.1111910

[15] Jarvela, S., Volet, S., \& Jarvenoja, H. (2010). Research on motivation in collaborative learning: moving beyond the cognitivesituative divide and combining individual and social processes. Educational Psychologist, 45(1), 15-27.

[16] Karimi, M \& Hamzavi, R (2017). The Effect of Flipped Model of Instruction on EFL Learners' Reading Comprehension: Learners' Attitudes in Focus Advances in Language and Literary Studies Vol. 8 No. 1.

[17] Kintsch, W. (1988). The role of knowledge in discourse comprehension: A construction-integration model. Psychological Review, 95, 163-182.

[18] Kintsch, W. (2012). Psychological models of reading comprehension and their implications for assessment. In J. P. Sabatini, E. R. Albro, \& T. O'Reilly (Eds.), Measuring up: Advances in how we assess reading ability. Plymouth: Rowman \& Littlefield Education.

[19] Lage, M. J., Platt, G. J., \& Treglia, M. (2000). Inverting the classroom: A gateway to creating an inclusive learning environment. The Journal of Economic Education, 31(1), 30-43.

[20] Lee, J., \& Jang, S. (2014). A methodological framework for instructional design model development: critical dimensions and synthesized procedures. Educational Technology Research and Development, 62(6), 743-765. https://doi.org/10.1007/s11423014-9352-7.

[21] Lee, G., \& Wallace, A. (2017). Flipped learning in the English as a foreign language classroom: Outcomes and perceptions. TESOL Quarterly, 1-23. https://doi.org/10.1002/tesq.372.

[22] Li, Z., Hai-Ming, W., Dong-Ge, W., \& Xiao-Juan, J. (2017). Application of flipped classroom in grammar teaching. Advances in Social Science, Education and Humanities Research, 90, 254-260. https://doi.org/10.2991/sschd-17.2017.51.

[23] McCarthy, J. (2016). Reflections on a flipped classroom in first year higher education. Issues in Educational Research, 26(2), 332-350.

[24] Millard, E. (2012). 5 Reasons Flipped Classrooms Work: Turning lectures into homework to boost student engagement and increase technology fueled creativity. University Business.com, 26-29. http://www.universitybusiness.com/article/5- reasonsflipped-classrooms-work.

[25] Nasri, M., \& Biria, R. (2016). Integrating multiple and focused strategies for improving reading comprehension and L2 lexical development of Iranian intermediate EFL learners. International Journal of Applied Linguistics \& English Literature, 6(1), 311-321.

[26] Kawinkoonlasate, P (2019). Integration in Flipped Classroom Technology Approach to Develop English Language Skills of Thai EFL Learners. Canadian Center of Science and Education. Vol. 12, No. 11.

[27] Kewen Xu (2020). The Development of Mongolian as a Minority Language in digital spaces. Journal of Contemporary Educational Research 4(2):73-76.

[28] Pirasteh, P \& Mirzaeian, V (2015). The Effect of Short Message Service (SMS) on Iranian EFL Learners' Attitude toward Learning English Language in India Vol. 15:2.

[29] Rahimi, M. (2009). The role of teachers' corrective feedback in improving Iranian EFL learners' writing accuracy over time: Is learners' mother tongue relevant? Reading and Writing, 22(2), 219-243.

[30] Richards J, Bohlke D. (2012). Four Corners 2: Cambridge: CUP.

[31] Songhao,H., Saito,K., Maeda,T., \& Kubo,T. (2011). Evolution from collaborative learning to symbiotic E-learning: Creation of new E-learning environment for knowledge society. US-China Education Review, 8(1), 46-53.

[32] Serrano, R, Stengers, H \& Housen, A. (2015). 'Acquisition of formulaic sequences in intensive and regular EFL programmes', Language Teaching Research, vol. 19, no. 1, pp. 89-106. https://doi.org/10.1177/1362168814541748.

[33] Toto, R., \& Nguyen, H. (2009). Flipping the Work Design in an Industrial Engineering Course. IEEE international Conference on Frontiers in Education Conference. San Antonio, Texas, USA: IEEE Press.

[34] Yee, N. (2010). Understanding reading comprehension: multiple and focused strategy interventions for struggling adolescent readers. Material thesis, University of Saskatchewan, Canada.

Mustapha Hajebi is an English language teacher in Department of Education, Bandar Abbas, Iran. He finished his undergraduate studies at Tehran University for Teacher Education, majoring in TEFL. His research interests include Second Language Teaching, Applied ELT, Speaking, Collocations and Educational Technology. 